\title{
PRESSURE AGGLOMERATION HERBACEOUS RAW MATERIALS INTENDED FOR CONSUMER PURPOSES
}

\author{
Krzysztof Mudryk, Jaroslaw Fraczek, Marek Wrobel, Marcin Jewiarz \\ University of Agriculture in Krakow, Poland \\ krzysztof.mudryk@urk.edu.pl,fraczek.ur@gmail.com, \\ marek.wrobel@urk.edu.pl,marcin.jewiarz@urk.edu.pl
}

\begin{abstract}
Herbs production in recent years is steadily increasing and in 2015 it was over $21 \mathrm{Gg}$. Such materials are produced most often in particulate form and dried to the moisture content below $10 \%$. Such processing makes this material very challenging in terms of transportation and logistics. The low bulk density as well as the need to protect them from weathering makes the storage and shipment of these materials costly. Taking into account the above arguments there is a need in the market to improve some properties of these materials, especially in terms of storage and logistics. The paper presents the study, where two types of dried herbs, which are extremely popular in the food industry, chives (Allium schoenoprasum L.) and parsley (Petroselinum crispum) were investigated. The main assumption was to improve the specific density of the product, while keeping the bulk properties of the product as well as minimizing formation of the dust. The study showed that the both types of dried herbs are materials with high potential in production of high quality agglomerates, without causing a significant increase in dusty fraction. This could lead to important improvements in processing of herbs, especially in the case of transportation and storage.
\end{abstract}

Keywords: herbs, compaction, agglomeration pressure, relieve.

\section{Introduction}

The production of herbs intended only for pharmaceutical purposes is estimated at over 0.5 million tons per year, while in Poland it was 11.8 thousand tons and accounted for $0.04 \%$ of total plant products purchased in 2012 [1]. Such amount puts Poland at the forefront of European producers alongside France, Spain, Germany and Austria.

Acquiring herbal plants has two basic sources, i.e. from field crops and from natural harvest. According to the CSO (Central Statistical Office) data, in 2015, field crops comprised about 70 species grown on a total area of 17 thousand ha, of which more than 21 thousand tons of herbal material are harvested per year [2]. The natural collection includes about 100 species of plants and provides catches of species on the market. The mass of plants harvested naturally ranges from 35 thousand tons and accounts for $25 \%$ of the total mass. Due to the trend to specialize in agricultural production and to limit the harvest of herbal plants growing in natural habitats, it will gradually decrease [3].

Estimating the exact amount of herbs obtained on the Polish market is a difficult task, because the production department, where production of herbal plants is small, is often overlooked in regional censuses. In 2015, herbal field crops accounted for only $0.16 \%$ of the total cultivated area in Poland.Difficulties associated with the unambiguous allocation of plants to the group of herbs are also a big problem. Plants, which taste values are valued much more than medicinal properties, are commonly considered as spices or even vegetables. An example of such plants are chives, parsley or dill. According to the CSO, dill is qualified for the "other" subgroup, groups of "vegetables" [2]. In contrast, chives are popularly considered as vegetables in publications [4], but treated as a herb. The authors of the work, based on literature could state that the group, which the plant is assigned to, depends mainly on the nature of its use, but hence the discrepancy is in nomenclature.

In Poland, the main direction of using herbs is to devote them to healing purposes mainly for the production of preparations intended for the treatment of the digestive system, which distinguishes our domestic market compared to other European markets.In addition to medicines, the production of herbal foods and cosmetics is also important [5]. Considering herbs intended for food production, they are mainly used for the production of fruit and herbal teas, and to a less extent, the production of essential oils and spices [6]. A marginal, but noteworthy destiny is the production of animal feed, where, just like fruit and herbal teas, only semi-finished products are used, i.e. crumbled dried plants.

Considering the main direction of using herbs in Poland, one can agree with the statement that "Analysis of the shaping of the plant medicines market, which is an integral part of the large pharmaceutical market in Poland, should be the starting point to answer the question: what will be the 
future of Polish herbal medicine?" [3]. The interest of older people in the treatment of natural methods with the use of herbal plants in Poland and in the world, as well as the fact that the society is aging, give reasons to believe that interest in herbal products will grow. The current promotion of a healthy lifestyle and the emergence of more organic products offered on the market of natural medicine products is also a factor influencing the additional increase in interest in herbal products (Skotnicka 2013).

In Poland, the herbal plant market has a strong and stable position in agriculture, created mainly by the demand for products or semi-finished products made from herbal plants $[3 ; 5 ; 7]$. It should be remembered that processing of these plants, in particular intended for the pharmaceutical industry, must follow the detailed rules, by which it is possible to obtain a product of satisfactory quality that can be used in further processing and above all suitable for consumption by consumers. One of the most important technological processes that determine the quality of the product is the drying stage. Drying is the oldest and the most popular method of preserving food products, the consequence of which is its greatest development. Used in industry and by growers, it is based on reducing the water content in the dried material by supplying energy (heating) and supplying the drying agent with appropriate parameters. Currently, drying of herbs is carried out in dryers using various technologies depending on their purpose and economic possibilities. It is worth noting that due to the high energy consumption of drying processes (consumption of energy used for drying purposes is estimated at approx. 10-12\% of total energy consumption in industry), the technology is aimed at reducing the energy consumption or improving the efficiency of the dryers already functioning [8].

Issues related to storage and transport of herbs pose problems on many levels ranging from the economic aspects of investment and costs to issues related to the capabilities of the infrastructure owned by the investor. Activities undertaken for the purpose of proper storage and transport of the material possessed depend mainly on the way it is fixed (transport also applies to the transport of fresh, unfixed plants), therefore, due to the scope of work, the authors will focus on plants fixed by drying.

The transport of herbal plants is demanding in terms of raw material preparation and transport preparation.During transportation, the raw material cannot be contaminated, therefore, in the case of transporting dried material, regardless of the species, the plant should be tightly packed without the possibility of airing, e.g., a paper bag lined with foil. Such packaging protects the product against accidental moisture or ingress of contaminants carried along with the air. In economic terms, poor preparation of the raw material or improperly selected means of transport that does not meet the minimum requirements as to the conditions of transport, result in a decrease in the value of the raw material and, as a result, in losses

From the entrepreneur's point of view, the limitation of transport is a positive operation due to the savings resulting from it.A large field for action are the possibilities associated with the use of the total truck loading. A good method of increasing the mass of the transported cargo is the density of the raw material (agglomeration to granular forms), which will increase its bulk density by two or three times. In this way, it is possible to better use the capacity of vehicles and, as a result, limit the number of journeys, which is equivalent to reducing costs. However, it should be remembered that the density of the raw material should not result in the loss of its quality. A loss of quality that will result in a loss of unit value may turn out to be a loss-making operation. It is worth noting that very often, in addition to the costs incurred for the transport itself, the entrepreneur must pack the raw material, load it and in the case of own transport, take the time to transport it, therefore, in the case of reduced journeys we also get time spent on these activities.

Pressure agglomeration (compacting) consists in compressing adequately prepared material into matrices and, as a result, obtaining briquettes or pellets. This process is very commonly used in solid biomass processing, pharmaceutical industry (tablet forming) and for compacting animal feeds. In order to obtain a permanent connection between the raw material molecules, direct contact between the grains of the material is necessary, which requires proper pressure. Analyzing the possibilities of agglomeration of dried herbal plants, it should be remembered that this is a delicate raw material and the agglomeration parameters depend to a large extent on how it will be used (extraction of oils, addition to dishes). The process must be carried out in such a way that during the process the active substances obtained from a given raw material will not be lost. 
The literature review showed that pressure agglomeration of herbs intended for consumption is a niche subject, on which there are few scientific reports. Two reports can be distinguished in the works related directly to the subject matter discussed. The first of these concerns pressure agglomeration of herbal vegetable mixtures [10]. The material compacted at work were herbal mixtures (crumbled on a $2 \mathrm{~mm}$ and $1 \mathrm{~mm}$ sieve), in three humidity configurations, the pressure used for the agglomeration was 11.1 MPa. On the basis of the results obtained, the following conclusions were presented: For the fraction shredded on a $2 \mathrm{~mm}$ sieve, the pressure used was too small to obtain tablets of the minimum quality (the pellets disintegrated);

1. The minimum humidity must have varied depending on the composition of the mixture,

2. The increase in humidity causes a very significant impact on the compressive strength.

The second report refers to the impact of pressure agglomeration on losses in peppermint oil [11]. The tests, identical to those previously described, were performed on a hydraulic press. The material was a fraction with a dried size above or below the size of $2.5 \mathrm{~mm}$ (square mesh), while the agglomeration pressure was incomparably higher than in the previously described publication, because it was $193.86 \mathrm{MPa}$. Based on the research, the authors showed that the density of the material to the level of $1.038 \mathrm{~g} \cdot \mathrm{cm}^{-3}$ resulted in loss of oil in the amount of about $9 \%$.

\section{Materials and methods}

Two dried species of herbal plants, were used in the study, i.e. chives (Allium schoenoprasum L.) and parsley (Petroselinum sativum Hoffm) used most often for seasoning purposes. It was obtained from an industrial producer producing for catering purposes.

Chives is an onion perennial of the garlic family, valued because of its taste and aromatic qualities widely used in gastronomy. The part is used dark green or green leaves with a tubular shape on which, in the case of an imperfect set, inflorescences appear in a pink-purple color. The leaves settle a mild onion flavor and delicately burning taste, after harvesting it is suitable for both processing and direct consumption. The leaves of chives have antioxidant properties and a high content of vitamins C, B2, A and calcium. Chives usually grow from sowing in row spacing $30-40 \mathrm{~cm}$ (it is also possible to grow from seedlings or vegetatively by dividing the clumps). The harvest is made 3 or 4 times depending on the crop most often in the second year (in the first collection unprofitable), the normal yield of fresh plants during the growing season is within 18-34.0 t.ha ${ }^{-1}$. Due to the decrease in the yield after the third year of cultivation, it is recommended that it should be renewed every 4 up to 5 years.

Parsley (Petroselinum sativum Hoffm) is a two-year-old plant from the Baldaszkowate family. Its original origin is the eastern part of the Mediterranean zone. It is a plant valued both for its taste and healing properties.It is used practically in its entirety, both white-stalk root growing up to $30 \mathrm{~cm}$ in length and leaves, green, pinnate can be 2 or 3 times. Parsley causes an increased amount of urine output and to a small extent it causes the secretion of saliva and gastric juice, which improves digestion and, like chives, also has large amounts of vitamin C (100 mg in $100 \mathrm{~g}$ of fresh leaves) (Ożarowski i Jaroniewski 1987).

The most common varieties are parsley and root parsley.In the first one we use only the aboveground part, the root is too hard to use for food. In the case of root parsley, we use both aboveground and underground parts, however, the aboveground part is weaker in terms of nutrient content and attractive appearance.

The tests were carried out on the material, which were the plants described above, i.e. dried parsley leaves and chives leaves. At the beginning, the condition of the obtained material was evaluated. It was delivered in tightly packed cardboard bags covered with foil. The material was homogeneous, healthy, dry to the touch and possessed a distinctive aroma characteristic of a given plant.

After the organoleptic assessment, research was carried out to determine the exact values of selected physical characteristics of the raw material, i.e. the grain size, moisture content and bulk density. Subsequent studies concerned the agglomeration process and the qualitative assessment of the obtained granulates (specific and dump density). The agglomeration process was carried out on a hydraulic briquetting machine with a die diameter of $50 \mathrm{~mm}$ using a compaction pressure of $47 \mathrm{MPa}$, 
and pelletization tests were carried out on a Kovo Novak pelletizing machine using a die with a hole diameter of $8 \mathrm{~mm}$ and a compression ratio of 4.2 .

\section{Results and discussion}

Raw material for testing according to the instructions of the producer had a moisture content in the range of 4.5-6\%. Its granulation was identical to that used in industrial production. For the purpose of identification, the determination of the granulometric composition was performed on a sieve screen using 7 braided screens with the mesh sizes 3.15, 2.0, 1.4, 1, 0.5 and $0.25 \mathrm{~mm}$ (Fig. 1) and determination of the bulk density (Table 1).

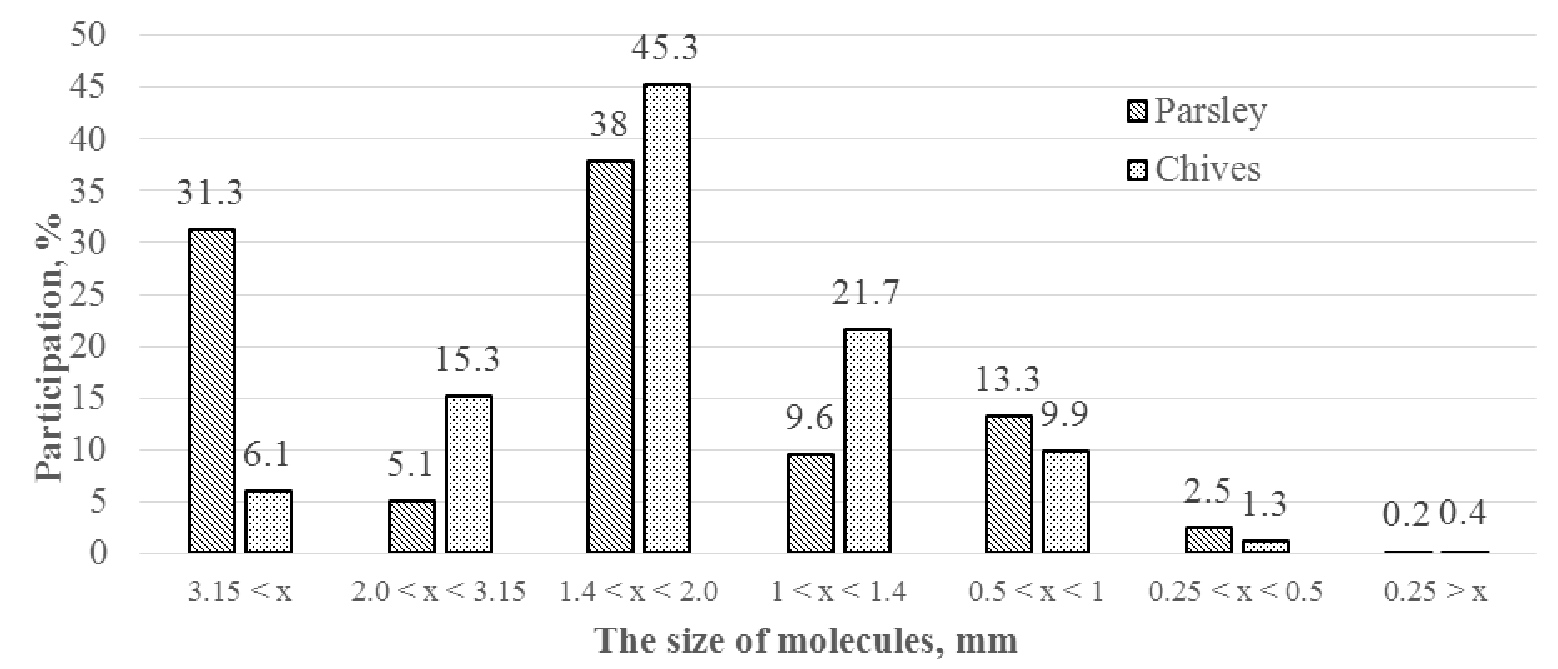

Fig. 1. Granulometric composition of raw materials tested

Table1

Results of the bulk density measurement of the raw materials tested

\begin{tabular}{|c|c|c|}
\hline \multirow{2}{*}{ Type of dried plant } & \multicolumn{2}{|c|}{ Bulk density BD, $\mathbf{~ k g} \cdot \mathbf{m}^{-\mathbf{3}}$} \\
\cline { 2 - 3 } & $\overline{\mathrm{BD}}$ & $\pm s$ \\
\hline Chives & 135.59 & 7.66 \\
\hline Parsley & 95.58 & 1.11 \\
\hline
\end{tabular}

The tests of compacting the dried material at the parameters for biomass intended for energy purposes enabled to achieve both pellets and briquettes of very good quality.An exemplary comparison of loose raw material with pellets and briquettes of the same weight is shown in Figures 2 and 3.

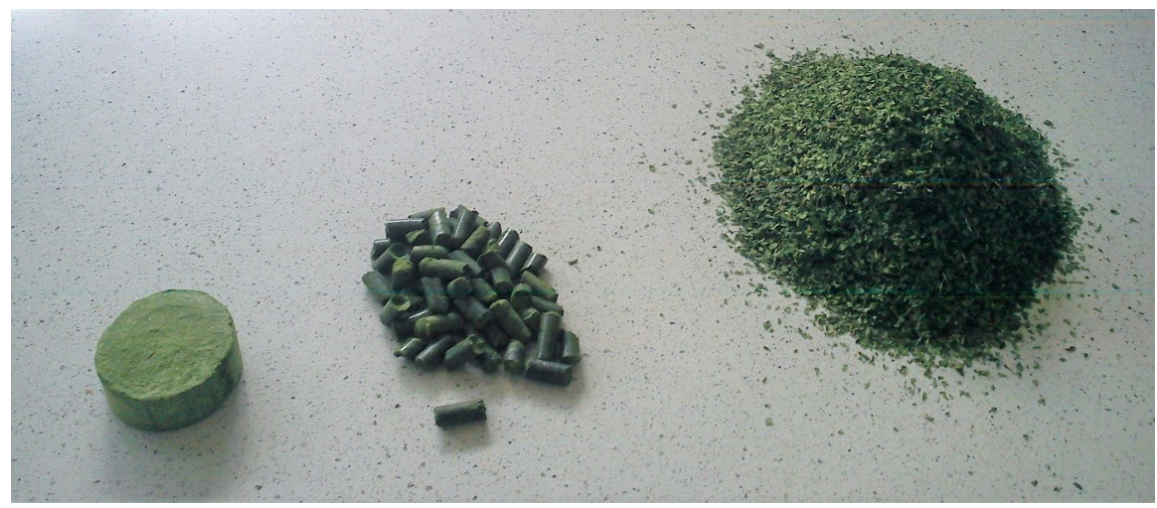

Fig. 2. Overview of raw material and granulated samples of parsley weighing $\mathbf{5 1} \mathbf{~ g}$

The results of determination of the specific and bulk density of the obtained granules are presented in Table 3. The specific gravity for parsley pellets was higher than for the pellets of chives, whereas in the case of briquettes the situation was reversed, because the briquettes of chives were more dense compared to parsley. It is also important that in both briquetting and pelleting the average 
specific gravity of parsley remained at a similar level of about $1090 \mathrm{~kg} \cdot \mathrm{m}^{-3}$, whereas in the case of chives, the briquettes had a density of $1246 \mathrm{~kg} \cdot \mathrm{m}^{-3}$, while the pellets had $1012 \mathrm{~kg} \cdot \mathrm{m}^{-3}$.

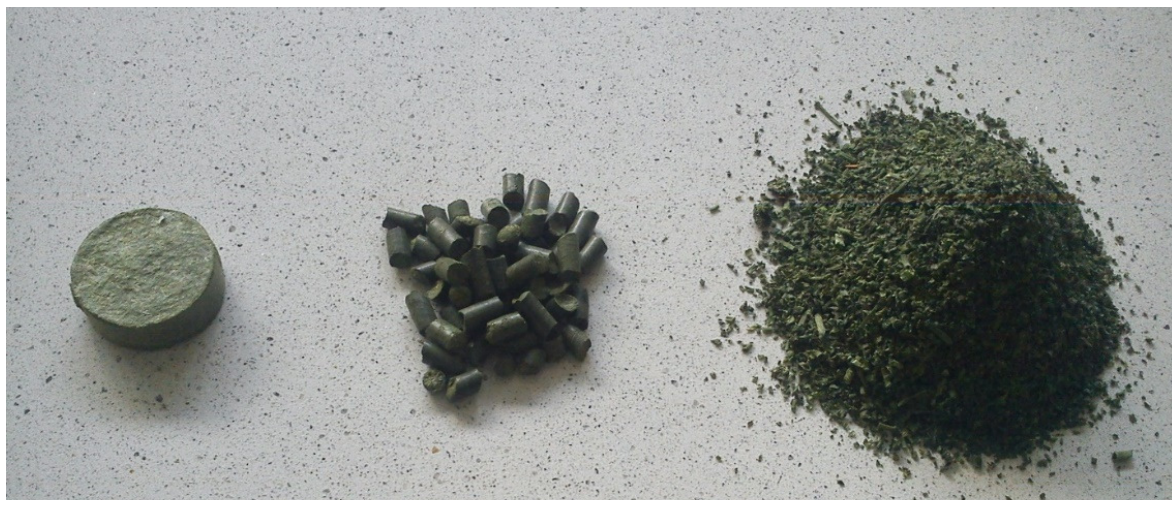

Fig. 3. Overview of raw material and granulated samples of chives weighing $43 \mathbf{g}$

The bulk density of the obtained pellets was also determined. This density is characterized by a relatively high value ranging from $696 \mathrm{~kg} \cdot \mathrm{m}^{-3}$ (chives) up to $799 \mathrm{~kg} \cdot \mathrm{m}^{-3}$ (parsley).Comparing the obtained results to the density of energy granulates, the density of which is in the range of 650$700 \mathrm{~kg} \cdot \mathrm{m}^{-3}$, it can be stated that these values are satisfactory, creating a relatively large space for further optimization work of processing technologies [12-17].

Table3

\section{Density measurement results for pellets and briquettes}

\begin{tabular}{|c|c|c|c|c|c|c|c|c|}
\hline \multirow{2}{*}{$\begin{array}{c}\text { Type of } \\
\text { granulate }\end{array}$} & \multicolumn{4}{|c|}{ Chives } & \multicolumn{4}{c|}{ Parsley } \\
\cline { 2 - 9 } & $\begin{array}{c}\text { Specific density } \\
\mathrm{SD}, \mathrm{kg} \cdot \mathrm{m}^{-3}\end{array}$ & \multicolumn{2}{c|}{$\begin{array}{c}\text { Bulk density } \\
\mathrm{BD}, \mathrm{kg} \cdot \mathrm{m}^{-3}\end{array}$} & \multicolumn{2}{c|}{$\begin{array}{c}\text { Specific density } \\
\mathrm{SD}, \mathrm{kg} \cdot \mathrm{m}^{-3}\end{array}$} & $\begin{array}{c}\text { Bulk density } \\
\mathrm{BD}, \mathrm{kg} \cdot \mathrm{m}^{-3}\end{array}$ \\
\cline { 2 - 9 } & $\overline{\mathrm{SD}}$ & $\pm s$ & $\overline{\mathrm{BD}}$ & $\pm s$ & $\overline{\mathrm{SD}}$ & $\pm s$ & $\overline{\mathrm{BD}}$ & $\pm s$ \\
\hline pellet & 1012.78 & 91.84 & 696.11 & 69.43 & 1104.34 & 114.57 & 799.52 & 4.11 \\
\hline briquette & 1246.85 & 130.39 & - & - & 1076.28 & 45.76 & - & - \\
\hline
\end{tabular}

One of the most important effects obtained in the agglomeration process is the relative high coefficient of agglomeration density. Relating the density of the agglomerate to the bulk density of the raw material, the density index was obtained for pellet 7.46 in the case of chives and 11.55 for parsley. Agglomeration of the studied raw materials into a form of briquette made it possible to obtain similar indicators ranging from 9.2 (for chives) to 11.2 (for parsley).These results clearly indicate that the process of agglomeration of herbaceous materials is of the greatest importance in the processes of storage and transport.

The topic of pressure compaction of herbal plants intended for consumption is an area, in which little research and information is available. Information and recommendations regarding the compaction of biomass (most often intended for energy purposes) often do not apply to dried plants intended for consumption. For this reason, it is necessary to continue the research towards compaction of herbal plants, in particular the study of energy consumption and the effect of compaction on the quality of the dried material (content of active substances, structure of the material).

\section{Conclusions}

1. The compaction process carried out on herbal raw material gives satisfactory results. The compaction index for parsley pellets was 11.55 and for chives 7.46. For the briquettes, the obtained values of this factor are similar. For parsley 11.2 and 9.2 for chives.

2. The specific density of the obtained granulates was relatively high and for pellets it ranged from $1012 \mathrm{~kg} \cdot \mathrm{m}^{-3}$ (for chives) to $1104 \mathrm{~kg} \cdot \mathrm{m}^{-3}$ (for parsley). In the case of briquettes, the density was similar and in the range from $1076 \mathrm{~kg} \cdot \mathrm{m}^{-3}$ (for parsley) to $1246 \mathrm{~kg} \cdot \mathrm{m}^{-3}$ (for chives).

3. The bulk density of the obtained pellets was similar to other granulates made of organic raw materials and it was in the range from $696 \mathrm{~kg} \cdot \mathrm{m}^{-3}$ (for chives) to $799 \mathrm{~kg} \cdot \mathrm{m}^{-3}$ (for parsley). 


\section{Acknowledgements}

The research was financed by the Ministry of Science and Higher Education of the Republic of Poland.

\section{References}

[1] Brostowski N., Poskrobko K. M., Tomasz Poskrobko and Sidorczuk- Pietraszkos E., "Analiza zapotrzebowania potencjału i wykorzystania surowców w regionie.” Hajnówka, 2014. pp. 17-23. [online] [20.03.2018]. Available at: http://powiat.hajnowka.pl/pliki/a2.pdf

[2] GUS. Wyniki Produkcji Roślinnej w 2015 r. Warszawa: GUS, Departament Rolnictwa, 2016.

[3] Skotnicka M. Rola ziół w żywieniu osób starszych - badanie pilotażowe. Probl Hig Epidemiol, 2013, pp. 635-638.

[4] Jambor J., Zielarstwo w Polsce - stan obecny i perspektywy rozwoju. Postępy Fitoterapii, 2007.pp. 78-81.

[5] Suojala T. "Yield potential of chive: Effects of cultivar, plastic mulch and fertilisation." Agricultural and Food Science, 2008.pp. 95-105.

[6] Mikołaczyk-Grzelak N. "Produkcja roślin zielarskich w Polsce." Roczniki Naukowe Stowarzyszenia Ekonomistów Rolnictwa i Agrobiznesu, 2008. pp.270-273.

[7] Olewnicki D., Jabłońska L., Orliński P., Gontar Ł. "Zmiany w krajowej produkcji zielarskiej i wybranych rodzajach przetwórstwa roślin zielarskich w kontekscie globalnego wzrostu popytu na te produkty." Zeszyty Naukowe Szkoły Głównej Gospodarstwa Wiejskiego w Warszawie 15, nr 1, 2015, pp. 68-76.

[8] Newril-Guz J. "Uprawa roślin zielarskich w Polsce." Roczniki Naukowe Stowarzyszenia Ekonomistów Rolnictwa i Agrobiznesu, 2016. pp. 268-274.

[9] Witrowa-Rajchert D.Nowe trendy w suszeniu żywności. Espertyza. Warszawa: AgEngPol, 2009. [online] [05.03.2018]. Available at:

http://www.agengpol.pl/LinkClick.aspx?fileticket=wq81Lx050Uc \%3D\&tabid=144

[10] Sobczak P. Wpływ składu mieszanek warzywno-ziołowych i czasu nawilżania na ich właściwości fizyczne oraz wytrzymałość tabletetk na ściskanie. Inżynieria Rolnicza, 2006. pp. 286-293.

[11] Sadowska U., Żabiński A. Mudryk K. Effect of the peppermint (MenthapiperitaL.) compaction process on the content of essential oils. Agricultural Engineering, 3 (155 );2015. pp. 83-88.

[12] Francik S.,Łapczyńska-Kordon B.,FrancikR., Wójcik A.Modeling and simulation of biomass drying using Artificial Neural Networks. Mudryk, Krzysztof, Werle, Sebastian (Eds.). Renewable Energy Sources: Engineering, Technology, Innovation - ICORES 2017. Springer 2018, pp. 571-582.

[13] Knapczyk A.,FrancikS., Francik R.,Ślipek Z.Analysis of possible application of olive pomace as biomass source. Mudryk, Krzysztof, Werle, Sebastian (Eds.). Renewable Energy Sources: Engineering, Technology, Innovation - ICORES 2017. Springer 2018, pp. 583-592.

[14] Knapczyk A., Francik S.,Wójcik A.,Bednarz G. Influence of storing Miscanthus $\times$ Gigantheus on its physical-mechanical and energetic properties. Mudryk, Krzysztof, Werle, Sebastian (Eds.). Renewable Energy Sources: Engineering, Technology, Innovation - ICORES 2017. Springer 2018, pp. 651-660.

[15] Wójcik A., Przybyła W., Francik S., Knapczyk A. The research into determination of the particlesize distribution of granular materials by digital image analysis. Mudryk, Krzysztof, Werle, Sebastian (Eds.). Renewable Energy Sources: Engineering, Technology, Innovation - ICORES 2017. Springer 2018, pp. 623-630.

[16] Wójcik A., Krupa K., Łapczyńska-Kondon B., Francik S., Kwaśniewski D.The dynamic model of willow biomass production. Mudryk, Krzysztof, Werle, Sebastian (Eds.). Renewable Energy Sources: Engineering, Technology, Innovation - ICORES 2017. Springer 2018, pp. 631-638.

[17] Mudryk K., Frączek J., Ślipek Z., Francik S., Wróbel M. Chosen physico-mechanical properties of cutleaf coneflower (Rudbeckialaciniata L.) shoots. "Engineering for rural development". Jelgava, 2013, pp. 658-662. 